\title{
TINJAUAN HUKUM ISLAM TERHADAP UPAH JASA PEKERJA SAWAH (Studi Kasus Desa Campurjo Kecamatan Wonomulyo)
}

\author{
Sri Wahyuni, Saifuddin
}

Prodi Hukum Ekonomi Syariah, Fakultas Agama Islam, Universitas Al-Asyariah Mandar

\author{
sriwahyuni3799@gmail.com
}

\begin{abstract}
Abstrak
Tujuan penelitian ini adalah untuk: 1) Untuk mengetahui sistem pembayaran upah jasa pekerja sawah di Desa Campurjo Kecamatan Wonomulyo, 2) Untuk mengetahui tinjauan hukum Islam terhadap sistem pembayaran upah jasa pekerja sawah di Desa Campurjo Kecamatan Wonomulyo. Jenis penelitian ini menggunakan jenis penelitian lapangan (field research) dan menggunakan pendekatan kualitatif. Sumber data yang digunakan adalah sumber data primer dan sekunder. Hasil penelitian ini menunjukkan bahwa dalam sistem pembayaran upah jasa pekerja di Desa Campurjo Kecamatan Wonomulyo yaitu ada tiga pekerjaan sawah yang diupahkan, yaitu pembajakan sawah, tanam (tandur), dan panen. Dalam pembajakan sawah upahnya dibayar panen berdasarkan luas lahan sawah. Untuk sistem pembayaran upah tanam (tandur) diberikan langsung saat pekerjaan selesai. Dan untuk sistem pembayaran upah panen diberikan langsung menggunakan gabah hasil panen. Sistem pembayaran upah dari tiga pekerjaan tesebut sudah sesuai dengan hukum Islam, di mana akad perjanjian yang dilakukan antara pemilik sawah dan pekerja sawah telah memenuhi rukun dan syarat ijarah karena telah dijelaskan mengenai besaran upah dan waktu pembayarannya sehingga tidak ada unsur penipuan di dalamnya yang dapat merugikan salah satu pihak.
\end{abstract}

Kata Kunci: Sistem Pembayaran Upah, Pekerja Sawah

\begin{abstract}
The purposes of this study are: 1) To find out the payment system for rice field workers' wages in Campurjo Village, Wonomulyo District, 2) To find out the Islamic law review of the payment system for rice field workers' wages in Campurjo Village, Wonomulyo District. This type of research uses field research and uses a qualitative approach. Sources of data used are primary and secondary data sources. The results of this study indicate that in the payment system for worker services in Campurjo Village, Wonomulyo District, there are three paid rice fields, namely plowing, planting (tandur), and harvesting. In plowing the fields, the wages are paid for harvest based on the area of the rice fields. The payment system for planting wages (tandur) is given immediately when the work is completed. And for the payment system for harvest wages, it is given directly using the harvested grain. The wage payment system for the three jobs is in accordance with Islamic law, where the contract agreement between the rice field owner and the rice field worker has fulfilled the pillars and conditions of ijarah because it has explained the amount of wages and the time of payment so that there is no element of fraud in it that can harm one of the parties.
\end{abstract}

Keywords: Wage Payment System, Field Worker 


\section{PENDAHULUAN}

Islam sebagai agama rahmatan lil alamin memberikan petunjuk dalam setiap kehidupan manusia baik sebagai individu atau dalam kehidupan sosial. Hal ini tak terkecuali dalam urusan muamalah dalam kehidupan sehari-hari. Islam sangat menekankan bagaimana berkehidupan dengan syariat agar tercipta cara berekonomi yang diinginkan. ${ }^{1}$

Muamalah sebagaimana yang dimaksud dengan istilah adalah pedoman Allah SWT, untuk mengkoordinasikan orang-orang sesuai masalah umum dalam lingkup sosial. ${ }^{2}$ Karena masalah muamalah ini secara langsung melibatkan masyarakat, aturan dan tindakan juga harus dipikirkan, sehingga tidak ada penyimpangan dan pelanggaran yang negatif bagi kehidupan dan hubungan antar manusia.

Muamalah adalah hubungan antara orang-orang yang dapat berubah sesuai kondisi. Salah satu jenis muamalah adalah tentang perjanjian atau kesepakatan kerja antara orang-orang sebagai penyedia jasa suatu manfaat atau tenaga dengan penyewa jasa yang memberikan pekerjaan. Sedangkan dalam Islam sewa-menyewa yang disebut dengan ijarah., yaitu bukan hanya pemanfaatan barang tetapi juga tenaga atau jasa dengan imbalan yang disebut dengan upah. Upah harus jelas, di mana sebelum pekerjaan selesai harus ada ketetapan yang tegas, tidak ada gharar.

Pada dasarnya, gaji atau upah diberikan dengan cepat, tetapi ketika perjanjian dapat berfokus pada upah atau menyelesaikannya. Jadi angsuran upah harus dibayar secepat mungkin sesuai dengan syarat-syaratnya dan upah harus segera diberikan ketika pekerjaan telah selesai. Pekerjaan yang dilakukan oleh individu yang dipekerjakan (dibayar) adalah perintah yang menjadi kewajibannya, ia menyelesaikannya dengan baik. Sehubungan dengan upah untuk individu yang direkrut, itu adalah kewajiban yang ditanggung oleh penghuni, dan ini adalah komitmen yang harus dia penuhi. ${ }^{3}$

Seiring dengan perkembangan waktu dan perkembangan zaman ke arah yang lebih modern, transaksi sewa menyewa menjadi berbeda dalam struktur dan teknik. Padahal strateginya kurang tepat dengan apa yang telah ditentukan oleh syariat Islam. Salah satunya adalah sistem pembayaran upah jasa pekerja sawah yang dilakukan masyarakat Desa Campurjo Kecamatan Wonomulyo, di mana dalam pengelolaan dan penggarapan sawah ada beberapa tahapan pekerjaan yang diselesaikan mulai dari musim tanam hingga panen. Diantaranya mulai dari pengolahan tanah untuk penanaman, pembajakan sawah, pemilihan bibit, pembibitan, penanaman (tandur), dan panen. Dari beberapa tahapan pekerjaan tersebut, ada tiga pekerjaan yang dilakukan dengan mempekerjakan orang lain, khususnya dalam hal pembajakan sawah, tanam (tandur), dan panen.

Ketiga pekerjaan tersebut tentu saja berbeda dalam kerangka pembayaran upahnya. Dimana dalam pembajakan sawah upahnya tidak dibayarkan secara langsung tetapi panen. Pada tahap penanaman (tandur), upah diberikan secara langsung ketika pekerjaan telah selesai. Selanjutnya, pada tahap panen upah dibayarkan langsung dengan menggunakan gabah sebagai upah.

Dalam Islam disyariatkan bahwa pembayaran upah atau kompensasi kepada orang yang telah memberikan jasanya harus dilakukan setelah pekerjaan selesai, dan tidak boleh menunda pembayaran upah karena ada kemungkinan bahwa pihak yang bersangkutan benar-benar membutuhkannya. Namun kenyataannya di Desa Campurjo Kecamatan Wonomulyo ada pembayaran upah yang diberikan bukan saat pekerjaan telah selesai. Dimana upah ditangguhkan dan akan diberikan pada saat panen, sedangkan Islam menganjurkan bahwa upah harus diberikan saat pekerjaan telah selesai.

\footnotetext{
${ }^{1}$ Amir Syarifuddin, Garis-Garis Besar Fikih, (Bogor: Kencana, 2003), h. 191.

${ }^{2}$ Hendi Suhendi, Fiqih Muamalah: Membahas Masalah Ekonomi Islam, (Jakarta: PT. Raja Grapindo Persada, 2002), cet, ke-1, h. 2.

${ }^{3}$ Saleh Al-Fauzan, Fiqih Sehari-Hari (Jakarta:Gema Imani Press, 2005), h. 488.
} 
Berdasarkan latar belakang masalah di atas, maka penulis sangat tertarik untuk meneliti lebih jauh mengenai sistem pembayaran upah jasa yang dilakukan antara pemilik sawah dengan pekerja sawah di Desa Campurjo Kecamatan Wonomulyo yang penulis tuangkan dalam karya ilmiah dengan judul "Tinjauan Hukum Islam Terhadap Sistem Pembayaran Upah Jasa Pekerja Sawah (Studi Kasus Desa Campurjo Kecamatan Wonomulyo)”.

\section{METODE PENELITIAN}

Jenis penelitian ini adalah penelitian lapangan (field research), khususnya penelitian yang berencana untuk berkonsentrasi secara serius tentang latar belakang keadaan sekarang, dan interaksi lingkungan suatu unit sosial, individu, kelompok, lembaga atau masyarakat. ${ }^{4}$ Lokasi penelitian ini adalah di Desa Campurjo Kecamatan Wonomulyo. Ada dua sumber data dalam penelitian ini yang akan dimanfaatkan oleh analis sebagai fokus data untuk membantu informasi yang dibutuhkan dalam penelitian, yaitu sumber data primer dan sumber data sekunder. ${ }^{5}$ Metode pengumpulan data terdiri dari observasi, wawancara, dan dokumentasi. Teknik pengolahan dan analisis data melalui tiga cara yaitu, reduksi data, penyajian data, dan penarikan kesimpulan. Teknik yang digunakan untuk menguji keabsahan data dalam penelitian ini adalah triangulasi. Triangulasi data adalah suatu metode pengecekan keabsahan data yang memanfaatkan sesuatu yang berbeda. Peneliti dapat memeriksa penemuannya dengan melihat berbagai sumber, strategi, atau hipotesis. ${ }^{6}$

\section{HASIL DAN PEMBAHASAN}

Di Desa Campurjo Kecamatan Wonomulyo, dalam hal pengelolaan dan penggarapan sawah terdapat tahapan-tahapan pekerjaan dari mulai tanam sampai panen, di antaranya yaitu persiapan lahan tanam, pembajakan sawah, pemilihan bibit, pembibitan, tanam (tandur), perawatan lahan sawah, dan panen. Dari tujuh tahapan pekerjaan tersebut, pekerjaan dengan mempekerjakan orang lain atau menyewa jasa yang dilakukan pemilik sawah di Desa Campurjo Kecamatan Wonomulyo untuk melakukan pekerjaan di sawahnya yaitu ada 3 pekerjaan, mulai dari pembajakan sawah, tanam (tandur), dan panen.

Hal tersebut sesuai yang dikatakan Bapak Tatang selaku pemilik sawah saat diwawancarai mengenai pekerjaan apa saja yang dilakukan dengan mempekerjakan orang lain atau menyewa jasa untuk melakukan pekerjaan tersebut:

Kalau saya itu pekerjakan orang atau sewa jasanya dalam pembajakan sawah, tanam, sama panen padi. Dalam pembajakan sawah saya menyewa jasa traktor bajak sawah (pa'dompeng) untuk membajak sawah saya. Tiba waktunya tanam saya menyuruh buruh tandur untuk menanam padi di sawah saya. Kalau waktunya panen saya menyewa jasa kombeng untuk memenen padi di sawah saya. ${ }^{7}$

Hasil wawancara di atas dengan Bapak Tatang selaku pemilik sawah, bahwa dalam pengelolaan sawah tidak semua pekerjaan bisa dilakukan sendiri oleh pemilik sawah, sehingga mereka membutuhkan bantuan orang lain atau jasa untuk membantunya dalam hal mengerjakan sawahnya. Di mana pekerjaan dengan mempekerjakan orang lain yaitu dalam pembajakan sawah,

${ }^{4}$ Cholid Narbuko, Abu Achmadi, Metode Penelitian untuk Skripsi dan Tesis Bisnis, (Jakarta: Bumi Aksara, 2009), h. 22.

${ }^{5}$ Sugiyono, Metode Penelitian Kuantitatif, Kualitatif dan $R \& D$, (Bandung: Alfabeta, 2009), h. 225.

${ }^{6}$ Lexy J. Maleong, Metodologi Penelitian Kualitatif, (Bandung : PT Remaja Rosdakarya, 2009), h. 330-332.

7 Tatang, Selaku Pemilik Sawah di Desa Campurjo Kec. Wonomulyo, Wawancara langsung pada Jumat 30 April 2021, Pkl. 16.00. 
tanam (tanam), dan panen. Dengan memberikan upah sebagai imbalannya atas jasa yang telah dipergunakannya dalam menegerjakan sawah pemilik sawah.

Dari tiga pekerjaan tersebut tentunya berbeda-beda dalam sistem pembayaran upahnya, yaitu sebagai berikut:

a. Pembajakan sawah

Dalam pembajakan sawah, pemilik sawah akan menyewa jasa traktor bajak sawah (pa'dompeng) untuk membajak sawahnya. Di mana sistem pembayaran upahnya tidak dibayar secara langsung tetapi dibayar panen. Upah yang dibayarkan adalah berupa uang berdasarkan pada luas lahan sawah pemilik sawah. Dengan perhitungan sawah yang luasnya 1 hektar besarnya upah yang akan dibayarkan adalah Rp. 1.000.000, dan sawah yang luasnya 1/2 hektar upahnya adalah sebesar Rp. 500.000.

Hal di atas sesuai dengan yang dikatakan oleh Bapak Sadar selaku pekerja sawah saat diwawancarai tentang sistem pembayaran upah jasa dalam pembajakan sawah:

Besarnya upah yang dibayarkan kepada pihak jasa traktor bajak sawah (pa'dompeng) itu berdasarkan luas lahan sawah, di mana upah tersebut dibayarkan pada saat panen. Untuk 1 hektar sawah itu upahnya sebesar Rp. 1.000.000, kalau 1/2 hektar berarti Rp. 500.000. Jadi upahnya itu tergantung sama luasnya sawah yang didompeng (dibajak). ${ }^{8}$

Wawancara dengan Bapak Puding selaku pemilik sawah juga mengatakan hal yang sama:

Pemilik sawah menyuruh saya untuk melakukan pembajakan di sawahnya. Kalau untuk upahnya itu dibayar panen sesuai dengan luas sawah milik pemilik sawah, ini sudah menjadi kesepakatan bersama sejak dulu. Misalnya sawah yang didompeng (dibajak) itu luasnya 1 hektar berarti upahnya Rp. 1.000.000, kalau 1/2 hektar yaa Rp. 500.000 upahnya. ${ }^{9}$

Dari hasil wawancara di atas bahwa dalam pembajakan sawah upahnya tidak dibayar secara langsung/kontan saat pekerjaan tersebut telah selesai, tetapi upah dibayarkan pada saat panen yang didasarkan pada luas lahan sawah pemilik sawah. Dengan perhitungan sawah dengan luas 1 hektar dikenai upah sebesar Rp. 1.000.000, kalau sawah dengan luas $1 / 2$ hektar berarti upahnya sebesar Rp.500.000.

b. Tanam (tandur)

Saat musim tanam, pemilik sawah akan menyuruh pekerja sawah yaitu buruh tandur untuk menanam padi di lahan sawah milik mereka. Dengan sistem pembayaran upahnya adalah dibayar langsung saat buruh tandur selesai melakukan pekerjaannya. Upah yang dibayarkan adalah dalam bentuk uang yang didasarkan pada luas lahan sawah pemilik sawah. Besarnya upah untuk buruh tandur yang diberikan oleh pemilik sawah adalah sebesar Rp. 1.200.000.

Hal di atas sesuai dengan yang dikatakan oleh Bapak Suyatno selaku pekerja sawah:

Pemilik sawah kalau mau tanam itu suruh buruh tandur untuk tanam padi di sawahnnya. Di mana buruh tandur itu terdiri dari sekolompok orang, baik laki-laki maupun perempuan. Sistem pembayaran upah untuk buruh tandur itu diberikan langsung setelah selesai tandur. Kalau upah untuk buruh tandur itu berdasarkan luas lahan sawah pemilik sawah dengan perhitungan upah adalah sebesar Rp. 1.200.000. ${ }^{10}$

${ }^{8}$ Sadar, Selaku Pihak Jasa Pembajak Sawah di Desa Campurjo Kec. Wonomulyo, Wawancara langsung pada Rabu 05 Mei 2021, Pkl. 09.00.

${ }^{9}$ Puding, Selaku Pemilik Sawah di Desa Campurjo Kec. Wonomulyo, Wawancara langsung pada Sabtu 08 Mei 2021, Pkl.19.00.

${ }_{10}$ Suyatno, Selaku Pihak Jasa Pembajak Sawah di Desa Campurjo Kec. Wonomulyo, Wawancara langsung pada Selasa 18 Mei 2021, Pkl.09.00. 
Wawancara dengan Bapak Suyatno selaku pekerja sawah di atas, mengatakan bahwa dalam penanaman padi pemilik sawah akan menyuruh buruh tandur untuk melakukan penanaman padi di sawahnya. Di mana mereka telah dari jauh-jauh hari mencari buruh tandur tersebut sebelum tanam. Buruh tandur tersebut terdiri dari sekelompok orang baik laki-laki maupun perempuan, dengan sistem pembayaran upah buruh tandur adalah dibayar langsung berdasarkan luas lahan sawah, yaitu dengan perhitungan upah sebesar Rp. 1.200.000.

Adapun wawancara dengan Bapak Amir selaku pemlik sawah saat diwawancarai mengenai upah jasa untuk buruh tandur juga mengatakan hal yang sama:

Sebelum tanam, dari jauh-jauh hari saya telah cari buruh tandur untuk melakukan penanaman padi di sawah saya. Biasanya buruh tandur tersebut terdiri dari 10-15 orang yang melakukan tandur. Di mana upah untuk buruh tandur itu dalam bentuk uang yang diberikan langsung ketika selesai tandur. Upahnya itu adalah sebesar Rp. 1.200.000 untuk buruh tandur. ${ }^{11}$

Hasil wawancara dengan Bapak Amir di atas menunjukkan bahwa saat musim tanam tiba, pemilik sawah akan mencari buruh tandur untuk tandur di sawahnya dari jauh-jauh hari. Di mana buruh tandur tersebut biasanya terdiri dari 10-15 orang, dengan upah yang diberikan adalah dalam bentuk uang yang didasarkan pada luas lahan sawah. Upahnya adalah sebesar Rp. 1.200.000 yang akan langsung diberikan ketika buruh tandur selesai tandur di sawah.

c. Panen

Pemilik sawah akan menyewa jasa combine (kombeng) saat panen untuk memanen padi di sawahnya. Istilah kombeng adalah sebutan mobil combine (mesin perontok padi) yang digunakan oleh masyarakat Desa Campurjo Kecamatan Wonomulyo. Adapun sistem pembayaran upahnya adalah dibayar langsung menggunakan gabah hasil panen. Dengan perhitungan 10 karung gabah, maka keluar 1 karung gabah sebagai upah untuk jasa kombeng. Sehingga jika dituliskan dengan perbandingan yaitu 10:1.

Hal di atas sesuai dengan yang dikatakan oleh Bapak Hasyim selaku pemilik sawah saat diwawancarai tentang sistem pembayaran upah jasa kombeng:

Saya menyewa jasa kombeng saat panen untuk memanen padi di sawah saya beberapa hari sebelum saya panen. Dengan menyewa jasa kombeng, upahnya adalah gabah dari hasil panen yang saya dapatkan. Kalau padi saya selesai di panen maka upahnya akan langsung diberikan kepada pihak jasa kombeng. Upahnya itu kalau 10 karung gabah yang didapat, maka keluar 1 karung gabah sebagai upah jasa kombeng. ${ }^{12}$

Menurut Bapak Hasyim bahwa dia mencari jasa kombeng beberapa hari sebelum waktu panen tiba. Dengan menyewa jasa kombeng upah yang diberikan adalah tidak dalam bentuk uang melainkan gabah dari hasil panen padi pemilik sawah. Dengan perhitungan 10 karung gabah hasil panen keluar 1 karung gabah sebagai upah jasa kombeng. Upah tersebut akan diberikan langsung kepada jasa kombeng saat selesai maelakukan pekerjaannya.

Adapun wawancara dengan Bapak Supri selaku pekerja sawah juga mengatakan hal yang sama:

Sistem pembayaran upah untuk jasa kombeng adalah diberikan langsung saat telah selesai memanen padi, dengan upah yang diberikan berupa gabah yang didapatkan dari

11 Amir, Selaku Pemilik Sawah di Desa Campurjo Kec. Wonomulyo, Wawancara langsung pada Sabtu 22 Mei 2021, Pkl. 16.30.

${ }_{12}$ Hasyim, Selaku Pemilik Sawah di Desa Campurjo Kec. Wonomulyo, Wawancara langsung pada Rabu 26 Mei 2021, Pkl. 1100. 
hasil panen. Kalau perhitungannya itu 10 karung gabah hasil panen keluar 1 karung gabah untuk upah jasa kombeng. ${ }^{13}$

Menurut Bapak Supri selaku pekerja sawah di atas, bahwa dalam sistem pembayaran upah jasa kombeng yaitu upahnya adalah gabah hasil panen yang diberikan secara langsung ketika telah menyelesaikan memanen padi. Di mana upah diberikan berdasarkan banyaknya gabah hasil panen yang didapat dengan perbandingan yaitu 10:1, yaitu untuk 10 karung gabah maka keluar 1 karung gabah sebagai upah jasa kombeng.

Dalam Islam, semua pekerjaan hukum dapat diterima dan sah jika rukun dan isi perjanjian telah dipenuhi. Hal utama tentang rukum dan syarat ijarah adalah keabsahan perjanjian. Apabila akad tersebut telah dipenuhi dan sah seperti yang ditunjukkan oleh hukum Islam, maka pada saat itu komitmen setelah itu adalah jaminan upah atau pemberian kompensasi atau upah untuk suatu tugas yang juga dikerjakan sebagai salah satu rukun ijarah. Kemudian, pada saat itu kewajiban mengenai pembayaran upah yaitu dilakukan setelah melakukan pekerjaan. Mengenai hal ini, ada komitmen untuk membayar biaya administrasi yang harus dipenuhi oleh penyewa jasa atau pemilik sawah setelah pekerjaan selesai.

Sistem pengupahan dalam Islam sebagaimana diatur dalam fiqh muamalah, tidak mengizinkan adanya komponen penyalahgunaan dan aturan kesetaraan harus dipertahankan, dan ini adalah hal yang paling penting. Secara umum, masalah harga upah atau gaji yang paling rendah atau titik puncak pemberian upah tidak ada standar peraturanya dalam Islam. Prinsip keadilan adalah tujuan utama dalam sistem penetapan upah dalam Islam.

Secara umum transaksi upah dalam Islam telah dilakukan oleh banyak orang. Salah satunya yaitu masyarakat muslim di Indonesia, dan bahkan yang beragama non-Islam juga melakukan atau mengenal tentang "upah". Hal ini dapat ditunjukkan dengan banyaknya jumlah tenaga kerja, baik itu karyawan perusahaan, pegawai negara, petani, peternak, nelayan, dan sebagainya. Di Indonesia bagian timur pada umumnya juga masuk dalam bagian kategori tersebut, khususnya di bagian wilayah Sulawesi Barat. ${ }^{14}$

Salah satunya adalah sistem pembayaran upah jasa yang dilakukan masyarakat Desa Campurjo Kecamatan Wonomulyo, antara pemilik sawah dan pekerja sawah yaitu melakukan akad perjanjian secara lisan. Akad perjanjian seperti ini sudah sejak lama dilakukan berdasarkan rasa saling percaya antara satu sama lain. Dalam akad perjanjian telah ditetapkan besarnya upah yang akan dibayarkan pemilik sawah kepada pekerja sawah dan waktu pembayaran upah tersebut.

Bagi pekerja sawah, besaran upah yang mereka peroleh telah memenuhi komponen pemerataan dan kepatutan. Salah satunya adalah dalam hal pembajakan sawah bukan sesuatu yang mudah karena membutuhkan tenaga tambahan, selain itu jika lahan sawahnya sempit, tingkat kesulitan dan bahaya tanggung jawabnya sangat tinggi.

Hal ini sesuai dengan penjelasan Hadis Riwayat Bukhari dan Muslim dari Ibnu Majah menyebutkan:

$$
\text { إِحنَجَمَ وَأَعْطَى الْحُجَامَ أَجْرَه. }
$$

Artinya:

Berbekamlah kamu, kemudian berikanlah upah kepada tukang bekam tersebut. (Riwayat Bukhari dan Muslim)

${ }^{13}$ Supri, Selaku Pihak Jasa Pembajak Sawah di Desa Campurjo Kec. Wonomulyo, Wawancara langsung pada Kamis, 03 Juni 2021, Pkl. 20.00.

${ }^{14}$ Andi Sudarmin Azis, J-Alif: Jurnal Penelitian Hukum Ekonomi Syariah dan Budaya Islam, Vol. 2, No. 2, Tinjauan Hukum Islam Terhadap Buruh Pattei Anjoro (Studi Kasus Desa Lekopa'dis Kecamatan Tinambung Kabupaten Polewali Mandar), (Polewali: Lembaga Penelitian dan Pengabdian Masyarakat Universitas Al-Asyariah Mandar, 2017). 
Hadis di atas memberikan pemahaman tentang strategi bagaimana kita melakukan kontrak ijarah, terutama dalam hal kepastian ukuran sewa yang harus dibayar. Penegasan upah sewa dalam perjanjian adalah sesuatu yang harus diketahui, hal ini untuk menghindari perdebatan di kemudian hari. Kedua pihak yang berinteraksi harus mengklarifikasi hak dan komitmen di antara mereka untuk menghindari adanya perselisihan. ${ }^{15}$

Penetepan upah jasa di atas setara dengan gagasan yang diterapkan oleh Taqyuddin anNabbani. Dimana cenderung terlihat bahwa standar dasar penetapan upah adalah kewajaran yang terletak pada kejelasan perjanjian (pertukaran) dan kewajiban untuk melakukannya. Kesepakatan dalam perburuhan terjadi antara buruh dan pengusaha. Artinya, sebelum buruh direkrut, harus jelas terlebih dahulu bagaimana upah yang akan diperoleh buruh. Upah mencakup ukuran upah dan sistem pembayaran upah. Sementara itu, Taqyuddin an-Nabbani mengusulkan penyelesaian kompensasi dengan gagasan ijarah, di mana ijarah adalah pemanfaatan jasa dalam akad perjanjian. Jika ijarah identik dengan buruh, yang digunakan adalah tenaganya. ${ }^{16}$

Dengan cara ini Taqyuddin an-Nabbani tidak mendasarkan upah dengan kebutuhan hidup. Dia mengkategorikan upah pekerja sehubungan dengan administrasi atau keuntungan yang diberikan oleh pekerja dengan penilaian utama pada administrasi ini secara lokal. Jika upah itu telah dinyatakan pada waktu yang disepakati, maka upah tersebut adalah upah yang dirujuk. Sekalipun jika upah itu belum dinyatakan atau ada suatu pertanyaan mengenai hal itu, maka pada saat itu yang diterapkan adalah upah yang sama. ${ }^{17}$

Dalam sistem pembayaran upah buruh tanam (tandur) yang diberikan langsung saat pekerjaan telah selesai, di mana pada dasarnya kompensasi atau upah diberikan dengan cepat, namun ketika perjanjian dapat dilakukan dengan berfokus pada upah atau menyelesaikannya. Sehingga angsuran upah harus diselesaikan sesuai kesepakatan dan harus diberikan dengan cepat ketika pekerjaan telah selesai.

Berdasarkan hadis yang diriwayatkan oleh Ibnu Majah, bahwa Nabi SAW bersabda:

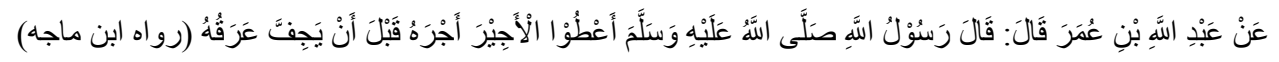

Artinya:

Dari Abdullah bin Umar ia berkata: "Rasulullah shallallahu 'alaihi wasallam bersabda: "Berikanlah upah pekerja sebelum kering keringatnya. ${ }^{18}$ (HR. Ibn Majah)

Hadis di atas mengungkapkan bagaimana memberikan etika dalam mempraktekan akad ijarah, khususnya memberikan angsuran upah secepat yang diharapkan. Kaitannya dengan akad ijarah yang berlaku saat ini adalah keharusan untuk mengangsur upah sesuai kesepakatan atau batas waktu yang telah ditentukan. Kita tidak boleh menunda pembayaran upah dari jadwal atau batas waktu yang telah disepakati. ${ }^{19}$

Bagaimanapun, sejauh mempercepat dan menunda pembayaran upah, beberapa ulama memiliki pendapat yang berbeda, antara lain:

Menurut mazhab Hanafi, kompensasi tidak hanya dibayarkan jika ada kesepakatan. Diperbolehkan memberikan syarat-syarat untuk mempercepat dan selanjutnya menangguhkan

15 Dimyauddin Djuwaini, Pengantar Fiqh Muamalah, (Yogyakarta: Pustaka Pelajar, 2008), h. 157.

16 Taqiyudin an-Nabbani, Membangun Sistem Ekonomi Alternatif Perspektif Islam, Terj.

Moh. Maghfur Wachid (Surabaya: Risalah Gusti, 2009), h. 108.

${ }_{17}$ Taqiyudin an-Nabbani, Membangun Sistem Ekonomi Alternatif Perspektif Islam, h. 108.

18 Panji Adam, Fikih Muamalah Maliyah (Konsep, Regulasi, dan Implementasi), (Bandung: PT Refika Aditama, 2017), h. 201.

${ }^{19}$ Djuwaini Dimyauddin, Pengantar Fiqh Muamalah, h. 157. 
kompensasi, misalnya kompensasi mempercepat dan menangguhkan sisanya, seperti yang ditunjukkan oleh pengaturan kedua pemain.

Jika tidak tercapai kesepakatan dalam hal penundaan atau percepatan upah, jika upah dikaitkan dengan waktu tertentu sehingga harus dipenuhi setelah jatuh tempo. Misalnya, jika seseorang menyewa rumah selama satu bulan, setelah masa sewa berakhir, ia harus membayar sewa. Jika kontrak untuk jasa, maka biaya jasa harus dibayar pada saat jasa telah dilakukan. Jika akad dilakukan tanpa syarat mengenai penerimaan pembayaran dan penangguhannya, Abu Hanifah berpendapat harus diserahkan secara bertahap sesuai dengan manfaat yang diterima.

Menurut Imam Syafi'i dan Ahmad, dia memenuhi syarat untuk menyetujui perjanjian tersebut. Dalam hal orang yang menyewa ( $\left.m u^{\prime} j i r\right)$ menyerahkan tenaga dan barang kepada orang yang menyewa (musta'jir), maka dia memenuhi syarat untuk mendapatkan semua angsuran karena penghuni telah memperoleh keuntungan dengan persetujuan. Juga, harus mendapatkan kompensasi guna mendapatkan tenaga kerja dan produk.

Untuk sistem pembayaran upah jasa combine (kombeng) yang langsung diberikan menggunakan gabah hasil panen, di mana pada tingkat dasar, semua yang dapat digunakan sebagai sarana perdagangan dalam jual beli diperbolehkan digunakan untuk angsuran dalam ijarah. Perlu diketahui ukuran upah oleh kedua pelaku, baik dalam hal sewa maupun upah.

Untuk mengetahui bagaimana pandangan Tokoh Agama terhadap sistem pembayaran upah jasa pekerja sawah di Desa Campurjo Kec. Wonomulyo, penulis melakukan wawancara dengan beberapa tokoh agama sebagai berikut:

Wawancara dengan Bapak Asep Sunaryat, beliau berpendapat bahwa:

Sistem pembayaran upah yang dilakukan antara pemilik sawah dan pekerja sawah itu sudah dilakukan sesuai hukum Islam. Di mana akad itu adalah kesepakatan antara kedua belah pihak. Apa yang menjadi kesepakatan itu yang menjadi hukum. Jadi akad seperti ini boleh yang penting sama-sama sepakat, tidak saling merugikan. Meskipun akad tersebut dilakukan secara lisan tidak secara tertulis, tapi masyarakat di sini menggunakan kepercayaan satu sama lain dalam melakukan akad perjanjian. Seharusnya memang dalam agama dianjurkan untuk melakukan akad perjanjian itu secara tertulis, tetapi itu sudah menjadi kebiasaan masyarakat di sini. Di mana kebiasaan di masyarakat itu bisa menjadi hukum. Dan dalam akad juga sudah sangat jelas diketahui oleh kedau pihak tentang besarnya upah yang akan diberikan dan kapan waktu pembayarannya. ${ }^{20}$

Menurut Bapak Asep Sunaryat, bahwa sistem pembayaran upah yang dilakukan antara antara pemilik sawah dengan pekerja sawah di Desa Campurjo itu sudah sesuai dengan hukum Islam. Di mana dalam melakukan akad itu dilakukan dengan sama-sama sepakat dan tidak saling merugikan satu sama lainnya. Dan dalam akad juga sudah sangat jelas diketahui tentang besarnya upah dan waktu pembayaran upah tersebut. Meskipun dalam Islam dianjurkan untuk melakukan akad secara tertulis, tetapi masyarakat menggunakan kepercayaan satu sama lainnya dalam melakukan akad perjanjian, sehingga sudah menjadi kebiasaan masyarakat. Di mana kebiasaan di masyarakat itu bisa menjadi hukum.

Adapun wawancara dengan Bapak Hasanuddin, beliau berpendapat bahwa:

Menurut saya nak, dalam sistem pembayaran upah yang dilakukan antara pekerja sawah dengan pemilik sawah itu sudah sesuai dengan hukum Islam. Di mana akad itu artinya dia sudah sepakat antara satu sama lain, tidak merasa berat atau merasa diberatkan, dan

${ }^{20}$ Asep Sunaryat, Selaku Tokoh Agama, Tinjauan Hukum Islam Terhadap Upah Jasa Pekerja Sawah di Desa Campurjo Kec. Wonomulyo, Wawancara langsung pada Kamis 10 Juni 2021, Pkl. 16.15. 
merasa memberatkan. Maksudnya satu sama lainnya itu sudah sama-sama sepakat dan tidak ada yang dirugikan. Karena sudah juga dijelaskan di awal akad tentang besarnya upah yang akan dibayarkan dan kapan waktu pembayarannya itu sudah jelas dan diketahui bersama antara kedua pihak. ${ }^{21}$

Hasil wawancara dengan Bapak Hasanuddin selaku Tokoh Agama di atas, beliau mengatakan bahwa sistem pembayaran upah jasa yang dilakukan kedua belah pihak yaitu antara pemilik sawah dan pekerja sawah di Desa Campurjo sudah sesuai dengan hukum Islam. Hal ini dikarenakan akad perjanjian yang dilakukan sudah sangat jelas, di mana telah dijelaskan di awal akad tentang besarnya upah yang akan dibayarkan dan kapan waktu pembayaran upah tersebut. Sehingga antara kedua belah pihak tidak ada yang dirugikan karena telah mengetahui secara jelas tentang pembayaran upah tersebut.

Berdasarkan hasil penelitian dari wawancara di atas, maka penulis dapat menyimpulkan bahwa dalam sistem pembayaran upah jasa pekerja sawah di Desa Campurjo Kecamatan Wonomulyo dalam hal pembajakan sawah, tanam (tandur), dan panen itu hukumnya adalah mubah/boleh dilakukan karena telah memenuhi rukun dan syarat ijarah, di mana dalam akad perjanjian yang dilakukan antara pemilik sawah dan pekerja sawah memuat tentang besarnya upah dan waktu pembayaran upah tersebut. Di mana upah yang dibayarkan sangat jelas sesuai dengan kesepakatan dan kedua belah pihak telah sama-sama mengetahui, sehingga tidak ada unsur penipuan maupun gharar di dalamnya yang dapat merugikan salah satu pihak.

\section{KESIMPULAN}

Berdasarkan dari hasil penelitian dan wawancara yang telah penulis lakukan tentang Tinjauan Hukum Islam Terhadap Sistem Pembayaran Upah Jasa Pekerja Sawah (Studi Kasus di Desa Campurjo Kecamatan Wonomulyo), maka penulis dapat mengambil kesimpulan sebagai berikut:

1. a. Sistem pembayaran upah untuk pembajakan sawah adalah upah dibayar panen berdasarkan luas lahan sawah, dengan perhitungan sawah yang luasnya 1 hektar upahnya adalah Rp 1.000.000, dan 1/2 hektar sebesar Rp. 500.000.

b. Sistem pembayaran upah untuk buruh tandur adalah diberikan langsung setelah pekerjaan telah selesai dalam bentuk uang, dengan upah yang didapat sebesar Rp. 1.200.000.

c. Sistem pembayaran upah untuk jasa combine (kombeng) adalah diberikan langsung menggunakan gabah yang didapat dari hasil panen, dengan perhitungan jika 10 karung gabah hasil panen maka keluar 1 karung gabah sebagai upah jasa kombeng.

2. a. Sistem pembayaran upah dalam hal pembajakan sawah di Desa Campurjo Kecamatan Wonomulyo hukumnya adalah mubah (boleh) dilakukan, karena telah memenuhi rukun dan syarat ijarah. di mana dalam akad perjanjian yang dilakukan antara pemilik sawah dan pekerja sawah memuat tentang besarnya upah dan waktu pembayaran upah tersebut. Sehingga tidak ada unsur penipuan di dalamnya yang dapat merugikan salah satu pihak.

b. Sistem pembayaran upah buruh tandur di Desa Campurjo Kecamatan Wonomulyo hukumnya adalah mubah (boleh) dilakukan, karena akad yang dilakukan sudah jelas mengenai besarnya upah dan waktu pembayarannya diberikan langsung saat pekerjaan tersebut telah selesai. Hal ini juga sesuai dengan yang dianjurkan dalam Islam, yaitu melakukan pembayaran upah saat pekerjaan telah selesai.

21 Hasanuddin, Selaku Tokoh Agama, Tinjauan Hukum Islam Terhadap Sistem Pembayaran Upah Jasa Pembajak Sawah di Desa Campurjo Kecamatan Wonomulyo, Wawancara langsung pada Minggu 13 Juni 2021. Pkl. 14.00. 
c. Sistem pembayaran upah jasa combine (kombeng) di Desa Campurjo Kecamatan Wonomulyo adalah mubah (boleh) dilakukan. Di mana dalam pembayaran upah diberikan langsung ketika pekerjaan telah selesai, meskipun pembayaran upahnya dengan gabah tetapi pada prinsipnya semua yang dapat digunakan sebagai alat tukar dalam jual beli adalah boleh digunakan untuk pembayaran dalam ijarah.

\section{DAFTAR PUSTAKA}

Adam, Panji. Fikih Muamalah Maliyah (Konsep, Regulasi, dan Implementasi). Bandung: PT Refika Aditama, 2017.

Al-Fauzan, Saleh. Fiqih Sehari-Hari. Jakarta:Gema Imani Press, 2005.

An-Nabhani, Taqiyudin. Membangun Sistem Ekonomi Alternatif Perspektif Islam. Surabaya: Risalah Gusti, 2009.

Azis, Andi Sudarmin. J-Alif: Jurnal Penelitian Hukum Ekonomi Syariah dan Budaya Islam, Vol. 2, No. 2. Tinjauan Hukum Islam Terhadap Buruh Pattei Anjoro (Studi Kasus Desa Lekopa'dis Kecamatan Tinambung Kabupaten Polewali Mandar). Polewali: Lembaga Penelitian dan Pengabdian Masyarakat Universitas Al-Asyariah Mandar, 2017.

Djuwaini, Dimyauddin. Pengantar Fiqh Muamalah. Yogyakarta: Pustaka Pelajar, 2008.

Maleong, Lexy J. Metode Kualitatif. Bandung : PT Remaja Rosdakarya, 2009.

Narbuko, Cholid dan Abu Achmadi. Metode Penelitian untuk Skripsi dan Tesis Bisnis. Jakarta: Bumi Aksara, 2009.

Suhendi, Hendi. Fiqih Muamalah. Jakarta: PT. Raja Grapindo, cet. ke-1, 2002.

Sugiyono. Metode Penelitian Kuantitatif, Kualitatif, dan R\&D. Bandung: Alfabeta, 2009.

Syarifuddin, Amir. Garis-Garis Besar Fikih. Bogor: Kencana, 2003. 